\title{
切りくず内金属組織の逆折れ現象*
}

上神謙次郎*1

\section{Back-Bending in the Primary Flow of Chip}

\author{
Kenjiro UEGAMI
}

\begin{abstract}
The primary flow in a chip may sometimes bend backward in the center of thickness a little toward rake face. This phenomenon occurs always when gaseous oxygen is blown against the cutting edge from the beginning of cutting carbon steel with the speed range in which built-up edge occurs. For this reason, it is that a wedge-type built-up edge with a sharp nose edge formed by the effect of oxide film occurs, the chip cut by the sharp built-up edge with a large rake angle impinges violently against the rake face of the tool and it is sheared again. The mechanism of the backbending of primary flow can be explained by considering shear planes having the angle of $\phi_{2,} \phi_{21}$ and $\phi_{22}$ in addition to the ordinary shear angle $\phi_{1}$.
\end{abstract}

Key Words: Cutting, Chip, Primary Flow, Wedge-Type Built-up Edge, Shear Plane

$$
\text { 1.はじめに }
$$

切削における切りくずは種々の情報を含んでおり， これによって切削現象を論ずることがしばしばなされ てきた。切りくず内の金属組織の流れの方向もその 1 つである。この切りくず内の金属組織の流れは刃先に おける激しいせん断変形の影響を大きく受けた結果生 じるもので，その流れ方向角には工具のすくい角とせ ん断角が関係している1 8)。この金属組織の流れは, 切りくずが生成されるせん断面での 1 次塑性流れ，そ して, 切りくずとすくい面との摩擦によって生じる2 次塑性流れとからなり，それらはいずれもすくい面側 に傾き，2 次塑性流れではさらによりすくい面に沿う ように湾曲して生じるのが一般に見られる現象である。

この金属組織の流扎が通常の場合とは異なり，切り くずのすくい面側のある範囲の厚さ内で， 2 次塑性流 れとは逆の方向に折机曲がる場合がある ${ }^{8}{ }^{9}$ ， 本論文 は、このような現象がどのような場合に生じるのか， そして，その生成機構について検討したものである。

2. 切削急停止写真の切りくず内金属組織の 逆折九例から

図1（a)，(b)蜘端面の切削による近似二次元切 削の急停止試料の断面（以下の写真もすべて同じ）を 研磨後腐食して金属組織を出した写真である。武料の 白い縁取りの層は研磨時の試料の縁の面だれ防止のた

* 原稿受付 1997 年 5 月 26 日.

*1 正員，大阪市立大学工学部（丞 558-8585 大阪市住吉区杉本 3-3-138)

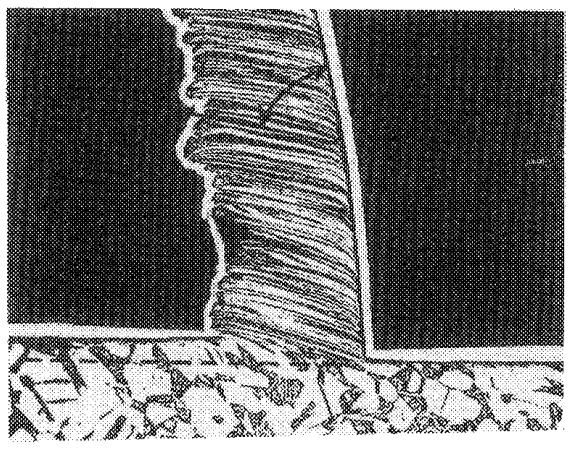

(a) $a$-brass, $\gamma_{\mathrm{T}}=-5^{\circ}, \quad \mathrm{V}=14 \mathrm{mpm}, \mathrm{d}=0.025 \mathrm{~mm}$

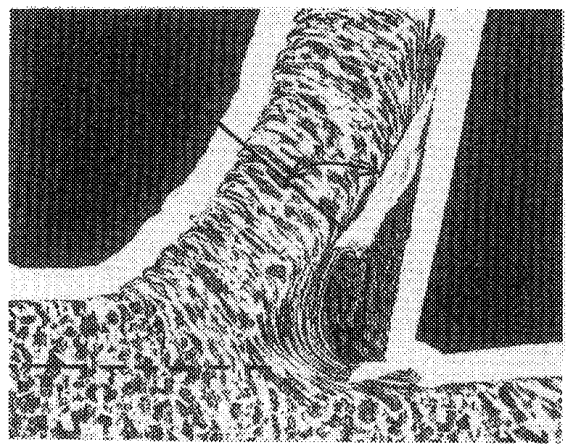

(b) $0.45 \% \mathrm{C}$ steel, $\gamma_{\mathrm{T}}=10^{\circ}, \mathrm{V}=18.2 \mathrm{mpm}, \mathrm{d}=0.1$ tam.

Fig. 1 The Abrupt-cutting-stop photographs

めに行った $\mathrm{N}$ i メッキの愿である。図1（a）は構成刃 先が生じていない七・三黄銅の切削の場合であり，同

（b）は炭素鋼 S $45 \mathrm{C}$ の鼻形構成刃先が生じている場合 である。これらの写真は一般によく見られるもので，

切りくず内には鮮明な金属組織の流れが見られ，2次 塑性流れはすくい面側に沿うように流れている。 


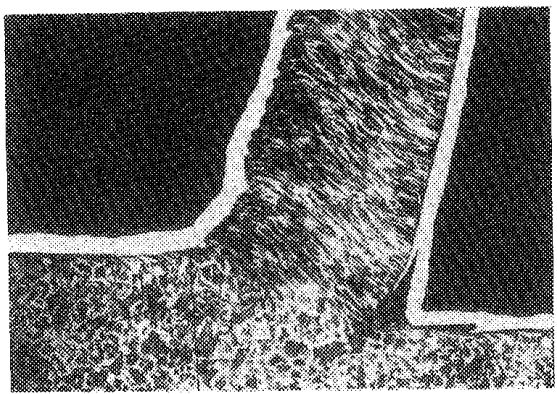

(a) $\gamma_{\mathrm{T}}=11^{\circ}, \mathrm{V}=20 \mathrm{mpm}, \mathrm{d}=0.2 \mathrm{~mm}$.

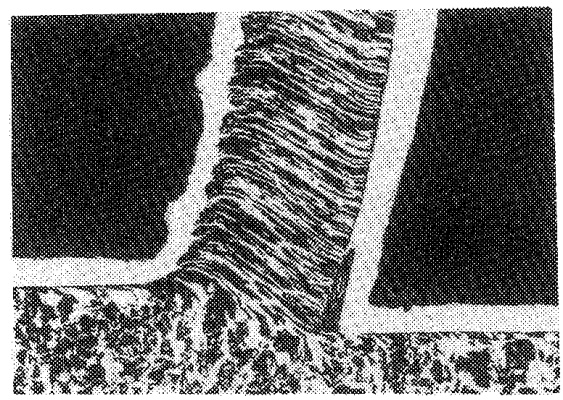

(c) $\gamma_{\mathrm{T}}=10^{\circ}, \mathrm{V}=5.2 \mathrm{mpm}, \mathrm{d}=0.1 \mathrm{~mm}$.

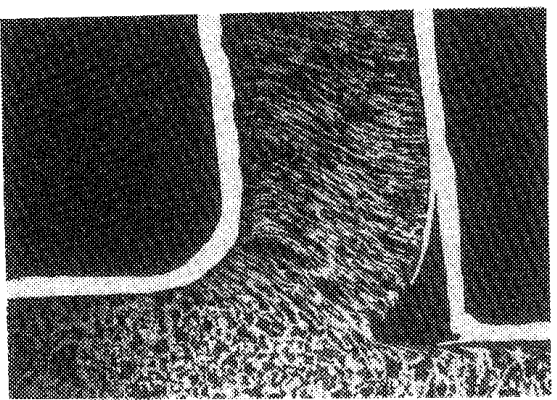

(b) $\gamma_{\mathrm{r}}=-5^{\mathrm{o}}, \mathrm{V}=20 \mathrm{mpm}, \mathrm{d}=0.2 \mathrm{~mm}$.

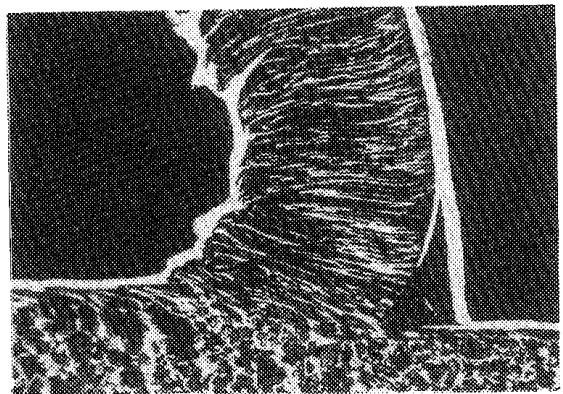

(d) $\gamma_{\mathrm{T}}=-5^{\circ}, V=5.2 \mathrm{mpm}, \mathrm{d}=0.1 \mathrm{~mm}$.
Fig. 2 The Abrupt-cutting-stop photographs with back-bending in the primary flow of chip when cutting $0.45 \% \mathrm{C}$ steel
図 2(a)〜 (d)の切削急停止写真は本諭で取り上げる ところの切りくず内の金属組織が逆折れを起こしてい る場合である ${ }^{8 \cdot 9)}$ 。写真から分かるように，切りくず 厚さのすくい面側の一定の範囲の層内の金属組織が, 図1の場合とは逆の方向に折机曲がっている。そして， すくい面との摩擦によると思われる2次塑性流れはす くい面側近傍の極く薄い層にわずかに生じているのみ である。そして、これらの写真の工具刃先にはいずれ も，図 1 (b) の鼻形ではなく，刃先が鋭い楔形の構成 刃先が形成されているのが特徴である.

このような楔形構成刃先は, 鉄鋼の構成刃先発生切 削速度域において，切削部分に気体酸素を噴射した場 合に発生する ${ }^{8 \sim 11}$ ， ままた，四六黄銅の極低速切削に おいても発生する ${ }^{8}$ 。この楔形構成刃先はいずれも脱 落・成長がほとんどなく，非常に安定している。その 結果仕上げ面粗さは高速切削時のように良好になる。

また，気体酸素の噴射を工具が被削材に接触する切 削前から行うか, 切削途中から行うかによって少し様 子が異なる9ー11)。すなわち, 工具为先が被削材に接触 する前から気体酸素を噴射してやると図 2(a) 〜 (d) の上うなすくい角の鋭い小さな形状の楔形構成刃先が 工其の刃先部分だけに生じる。そして，この上うな場 合切りくずは楔形構成刃先のすくい面を通過した後, 激しく工具すくい面に衝突するように当たって，切り くずの排出方向が強制的に曲げられている。このため， 切削力は必ずしも低くならず，鼻形構成刃先が生じて いる場合よりもむしろ高くなる場合がある(0).しかし， 切削力の変動は少なくなる10).

他方, 図 3 は切削途中から気体酸素索噴射した場合 の例で, 図1(b) のょうにすでに鼻形構成刃先が生じ
ている状態に気体酸素を噴射する。そうすると，鼻形 構成刃先の先端の上に楔形構成刃先が生じ, 全体とし て大きな楔形の構成刃先が生成され，この大きな楔形 構成刃先のすくい面に沿って切りくずは排出されるの で，工具のすくい面に接触しない加，たとえ接触して も十分刃先から離れた位置になる10?。このため，切り くずは工具すくい面に衝撃的に当たることはなく，切 削力は鼻形構成刃先が生じていた場合よりもさらに低 くなり，かつ変動も少なく安定し，仕上げ面粗さも非 常に良好になる。そして，切りくず内の金属組織は図 3 の写真から分かるように逆折れは生じない。

図 4 は四六黄銅の例を示す。四六黄銅を低速で切削 すると、この写真のように小さな楔形構成刃先が生じ る.そして，前述したのと同様に切りくず内の金属組 織は逆折れを起こしている。四六黄銅に生じる楔形構 成刃先については，星ら12.13) むその著書の中で述

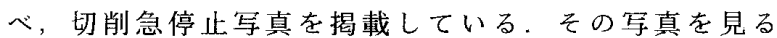
と明らかに切りくず内で金属組織が逆折れを起こして いるのが認められるが，星らはこの金属組織の逆折れ については特に言及していない。

図 5 は二段すくい角（すくい面拘束工具：すくい角 $\left.0^{\circ}, 30^{\circ}\right)$ 工具を用いて，四六黄銅を低速切削した場 合である。この場合にも鋭利な楔形構成刃先が生じる

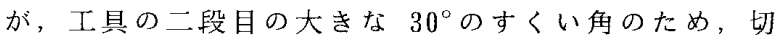
りくずは構成为先終端から強制的に曲げられることな く排出される。このため，切りくず内の金属組織の流 れに逆折れは生じていない。

以上のようにこれらの一連の切削急停止写真から, 切りくず内の金属組織に逆折れが生じる原因は次のよ うにいえる。すなわち，鋭いすくい角をもった小さな 


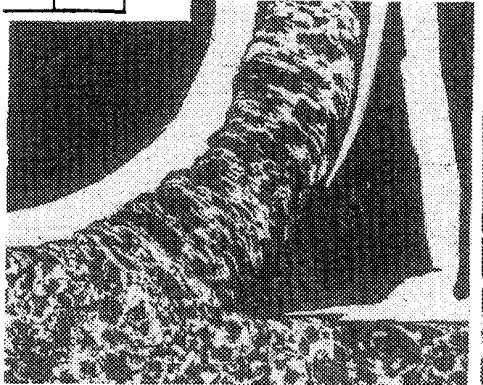

Fig. 3 The large wedge-type BUE when cutting $0.45 \% \mathrm{C}$ stee1 with gaseous oxygen jet

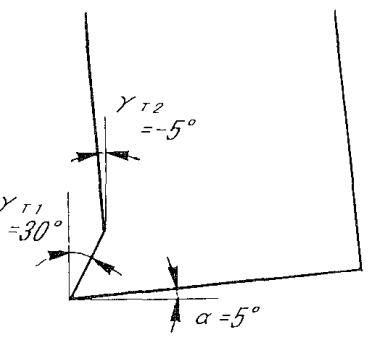

(a) inverse double rake tool

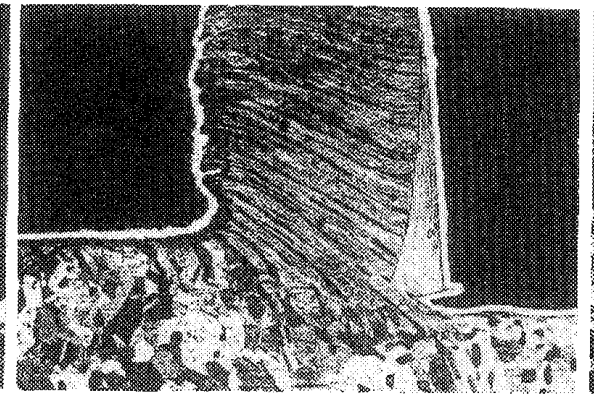

Fig. 4 The wedge-type BUE when cutting $\beta$-brass at $-5^{\circ}$ rake angle

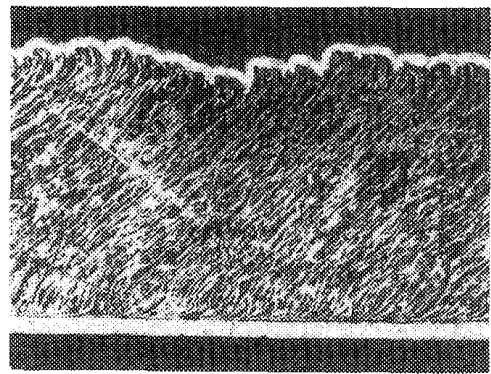

(b) chip

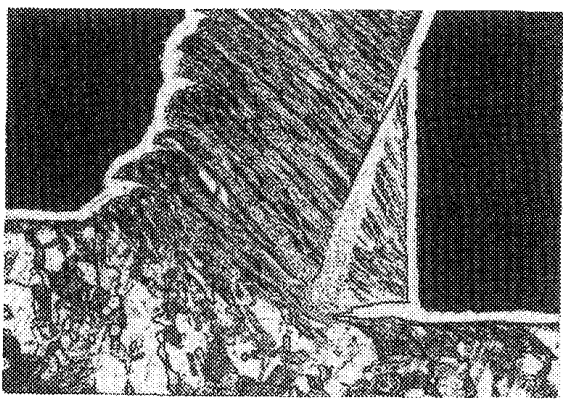

Fig. 5 The wedge-type BuE when cutting $\beta$-Brass at $-5^{\circ}$ and $30^{\circ}$ rake angle

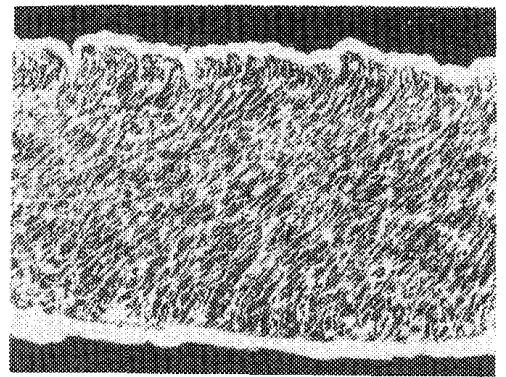

(c) chip

Fig. 6 Double rake angle tool and back-bending in the primary flow of chip

楔形構成刏先が生じる条件で切削すると，切りくずは まず，この楔形構成刃先によって生成され，構成风先 のすくい面に沿って流出するが，工具すくい面が近接 しているため，切りくずはすくい面に激しく衝突する ように接して，再び変形させられる。この変形の祭に， すくい面側の方が自由面側より変形が大きくなるため， 金属組織に逆折れが生じる

これを実証するため，逆 2 段すくい角工具とも言え る図6(a)に示す刃先形状をした工具を研削して製作 し，この工具により構造用炭素鋼 S45C党切削した。 切削速度は 100 四/ minで, 構成刃先が発生しない速度 域を選んだ。この場合，速度が速いため十分な急停止 操作ができなかったことと，刃先の破損が頻繁に起こ り，完全な急停止陚料が得られなかった。そこで，定 常切削時に得られた切りくずの繸断面の金属組織写真 を図6(b)おょび(C)に示す。これらの切りくず内の金

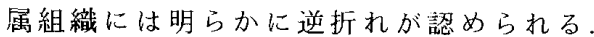

\section{3. 切りくず内の金属組織の逆折孔生成機構模型}

上述のように切りくずがせん断面で 1 次塑性変形を 受けた後，工具すくい面によって切りくずの排出方向 が強制的に変えられ，その際に再び変形を受けるもの として図2の各々の写真を詳細に観察すると，以下に 述べる現象が起こっていることが認められる。

図2の各写真に注目する。被削材はまず潔形構成刃 先によって単一せん断面々みなせる面で切りくずに変
形されている。このせん断面を通過した直後では，切 りくずの金属組織の流れは一様で構成刃先すくい面に 近い層でも未だ逆折机は生じていなくて，切りくずは 楔形構成刃先のすくい面に沿って上昇している。また， 切りくずの自由面は楔形構成刃先のすくい面に平行に なっている。さらに切りくずが上昇すると楔形構成刃 先のすくい面長さのほぼ中央に当たる付近から切りく ずの裏面が構成刃先すくい面から離れ始めている。こ の分離点から切りくず内に向かう境界で金属組織の逆 折れが若干生じている。そして切りくずが構成刃先す くい面から離れ工具すくい面に再接触するまでの空隙 の形状はほほ二等辺三角形とみなせる。

つづいて切りくず襄面が工具すくい面に再び接触す る点から，同じく切りくず内に向かって金属組織の逆 折机が再び大きく生じている。そして，この時点以後 の切りくずの自由面は工具すくい面に平行になってい る。また，切りくずの自由面側の層の金属組織の流れ 角に注目すると，切りくずが構成刃先すくい面上から 工具すくい面上に曲がり移る際に再せん断され，金属 組織の流れは少し変化している。これらの観察結果か ら次のような切削機構模型が考えられる。

図 7(a) は工具刃先に楔形構成成先が生じて, 切り くず内の金属組織が逆折れを起こす場合の切削機構模 型である。工具すくい面 K N 上に楔形構成㹝先 A I ) N があり，単一せん断面を四つ（A B， E C , E F ， E G）組合せた模型で，以下これについて述べる。

まず，図 2 のいずれの写真でも切りくず裹面が構成 


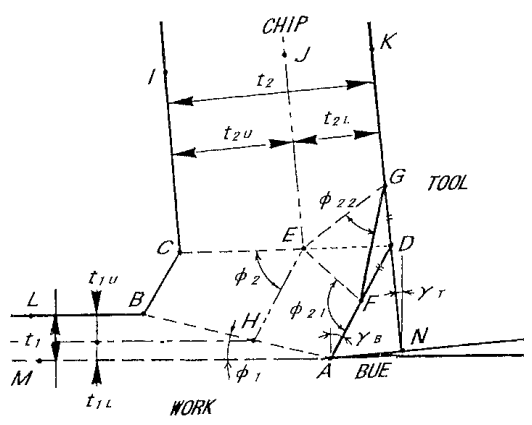

(a) Yodel of cutting mechanism with small wedge-type BUE

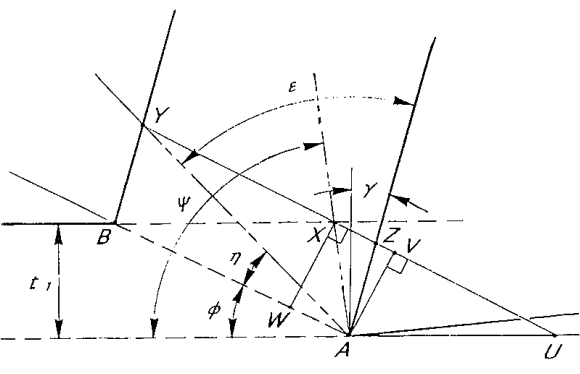

(b) Generating mechanism of primary flow in chip

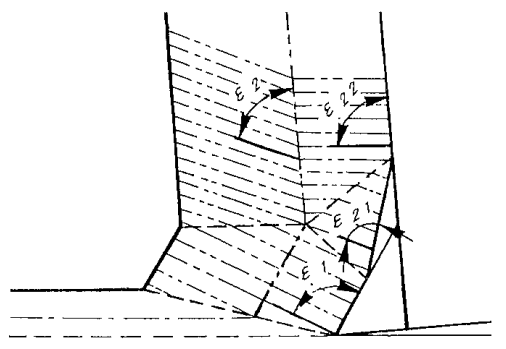

(c) Typical model of backbending in the primary flow of chip

Fig. 7 Cutting mechanism for generation of back-bending in the primary flow of chip

刃先すくい面長さのほぼ中央に扰いて離れていること， そして, 計算の簡単化も含めて前述の空隙 D F G を二 等辺三角形亡仮定する。したがって，構成刃先すくい 面 A D の中点を Fとし, 構成刃先の終端 D か D F = D $\mathrm{G}$ となる点 $\mathrm{G}$ を工具すくい面上にとる。るして，切 りくずの䘚面が A F G K の順に移動して切削圈外に排 出されるとする.

せん断面 A B の自由面側のB から構成为先すくい面 A D に平行に上に向けて線を引き, 同じく切りくず自 由面Iから工具すくい面 $\mathrm{K} D$ に平行に下に向けて線を 引き,これら平行線の交点を Cとする。そして、CD を結ぶ線を第 2 のせん断面とする。ただし，このせん 断面 C D の E C 部分のみが切りくずの自由面側の層に 関係し，DE 部分は切りくず下層部には関与しない。

切りくず内の二点鎖線は逆折れを起こしている層の 境界線であり，同じ比率の厚さで構成刃先上の切りく ず内，さらに被削材内まで延長して描いている。すな わち,この二点鎖線は, 工具すくい面 D K に平行で C $\mathrm{D}$ との交点を $\mathrm{E}$ とする。 $\mathrm{E}$ 点から構成刃先すくい面 $\mathrm{A}$ $\mathrm{D}$ に平行線を引き，せん断面 $\mathrm{AB}$ 而交点を $\mathrm{H}$ とする。 $\mathrm{H}$ から切込歹線 A M に平行線を引く。この線から下の 切込み社の下層 $\mathrm{t}_{1 \mathrm{~L}}$ は逆折れを生じる被削材の層であ る。そして，E F おょび $\mathrm{E} \mathrm{G}$ 老結び，これら 2 面を切 りくずのすくい面側の層に逆折れを生じさせる二っの せん断面とする。

このように仮定し, 切りくずは次に述べるように生 じるとする。まず最初に, 切込み七。の被削材は構成刃 先のすくい面 A D によってせん断面 A B を生じて切削 され切りくず A B C E F になる。つぎに工具すくい面 によって切りくずは強制的に変形させられるが, 切り くずの上層部である自由面側の H B C E 領域は第 2 の せ九断面 C E ( C D ) により再度せ九断され，工具す くい面に平行に変形され, C E J I となる。一方, 切 りくず裹面（すくい面）側の A H E F 領域はせん断面 E Fにより再せ九断され，F G に平行に進み，さらに せん断面 $\mathrm{GE}$ Eょって再々せん断されて工具と平行に なり， GE J K と変形する。すなわち，せん断面 $\mathrm{A} \mathrm{B}$
で形成された金属組織の流れ角が，これら一連のせん 断変形により順次再配列されて, 自由面側とすくい面 側とで差が生じ，すくい面側の方が大きな角度を取る 場合に図 7 (c)で示すような逆折れとなる.

\section{4. 金属組織の逆折れ角の算出}

切りくず内の金属組織の流れ角をはじめとして, 被 削材側面に描いた格子および被削材が瀻維状組織をむ つ場合の切りくず内での組織の流れ角などはすくい角 とせん断角によって定まることを以前に報告した8 。 図 7 (b)はその角度関係を示している.

図7 (b)に打いて, 寸くい角 $\gamma$ でせん断角 $\phi$ の切削 が行われている場合を考える。いま，図 8(a)，(b)に 圧延によるフェライトバンドなどによる繊維状の組織 が残っている被削材の切削急停止写真例を示す。この 繊維状組織の方向と切削方向之のなす角を $\phi$ として， 図 7 (b) の工具刃先 A から図のように $\phi$ を之る. 図 7 (b)において, 被削材 A B X U はせん断面 A B によっ て単純せん断されて切りくず $\mathrm{A} \mathrm{B} \mathrm{Y} \mathrm{Z} \mathrm{となる。そして,}$ 被削材中の繊維状組織 $\mathrm{A} \mathrm{X}$ は切りくず内で A Y と引伸 ばされ再配列され，せん断面となす角 $\angle \mathrm{BAY}=\eta$ を とるとする。これらは単純な幾何学関係から，

$$
\begin{aligned}
\tan \eta & =A V / V Y=A V /(V Z+Y Z) \\
& =A V /\left\{A V \tan (\phi-\gamma)+t_{1} / \sin \phi\right\}
\end{aligned}
$$

となり, A V は

$$
\begin{aligned}
& \mathrm{AV}=W X=W \tan \phi=(\mathrm{AB}-\mathrm{AW}) \tan \phi \\
&=\left\{\mathrm{t}_{1} / \sin \phi-\mathrm{AV} \cot (\phi-\phi)\right\} \tan \phi \\
& \therefore \quad \mathrm{AV}=\mathrm{t}_{1} /\{\cos \phi+\cot (\phi-\phi) \sin \phi\}
\end{aligned}
$$

となりっこれを上式に代人して、整理すると

$$
\cot \eta=\tan (\phi-\gamma)+\cot \phi+\cot (\phi-\phi) \cdots \cdots(1)
$$




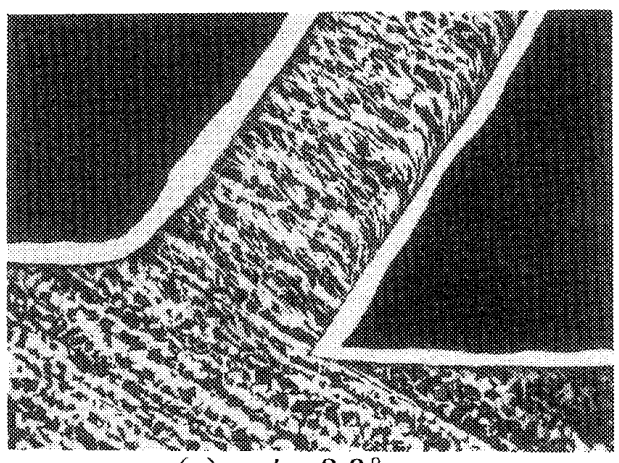

(a) $\phi=30^{\circ}$

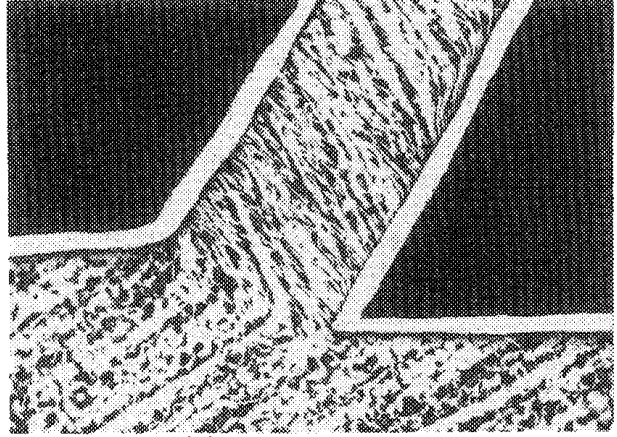

(b) $\phi=150^{\circ}$

Fig. 8 The Abrupt-cutting-stop photographs when cutting the fibrous structure $0.45 \% \mathrm{C}$ stee 1

となる。

繊維状組織でない通常の金属組織の被削材では，せ ん断面之 $\pi / 4$ の方向の被削材が最も引き延ばされ， 切りくず内で A Y の方向に再配列されることを以前に 奏証した ${ }^{8)}$ 。したがって，式(1)を $\phi=\phi+\pi / 4$ として,

$\cot \eta=\tan (\phi-\gamma)+\cot \phi+1 \ldots \ldots \ldots \ldots(2)$

とすればよい。また，被削材側面に格子線を描きその 縦線が切りくず内でなす角は, 同様に $\phi=\pi / 2$ と すればよいことも以前に確認しており8，

$\cot \eta=\tan (\phi-\gamma)+\cot \phi+\tan \phi \cdots \ldots \ldots(3)$

となる。本論に関与するのは(1)式および(2)式である. そして，図7(b)のように金属組織の切りくず内での 流れ角はクよりも，切りくず裹面とのなす角 $\varepsilon$ の方が 測定しやすいから，

$\varepsilon=\pi / 2-\eta-(\phi-\gamma)$

から，式(1)および(2)を書き改めると，

$\varepsilon=\tan 1 \tan (\phi-\gamma)+\cot \phi+\cot (\phi-\phi)\}-(\phi-\gamma)$ $\cdots(4)$

$\varepsilon=\tan 1\{\tan (\phi-\gamma)+\cot \phi+1\}-(\phi-\gamma) \cdots(5)$

となる、本現象においては, まず, 図7(a)のAB C $\mathrm{EF}$ 域の金属組織の流机角 $\varepsilon_{1}$ は通常の金属組織の被 削材によるものであり，切りくず内における組織の流 れ角は式(5)にもとづき，

$\varepsilon_{1}=\tan { }^{1}\left\{\tan \left(\phi_{1}-\gamma_{B}\right)+\cot \phi_{1}+1\right\}-\left(\phi_{1}-\gamma_{B}\right)$ $\cdots \cdots(6)$

となる。

つぎに, C E I J 領域の流机角 $\varepsilon_{2}$ は, $\mathrm{HE}$ E進ん

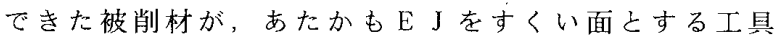

によって切削され，せ九断面 C Eによって切りくず C E J I を生じたごとく変形されると考え, 式(4)の

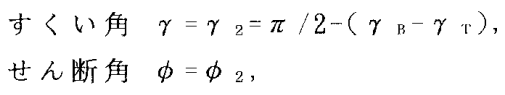

とし，すでに繊維状組織が形成されているから，その 組織が切削方向となす角 $\phi=\pi-\varepsilon$ ，として代入し，

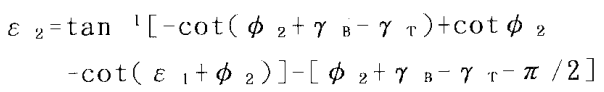

となる。

切りくず下層部においても同様であり， E F G 領域 での流れ角を2、は

$\gamma=\gamma_{21}=\pi / 2-1 / 2\left(\gamma_{\mathrm{B}}-\gamma_{\mathrm{T}}\right), \quad \phi=\phi_{21}, \quad \phi=\pi-\varepsilon$ । から

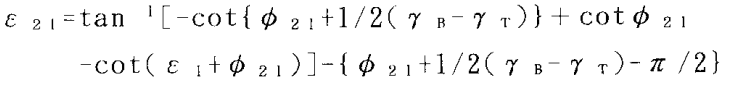

5. 計算結果のまとめ

前項にもとづいて図 2(a)の切削急停止写真につい て調バた。同図写真から 


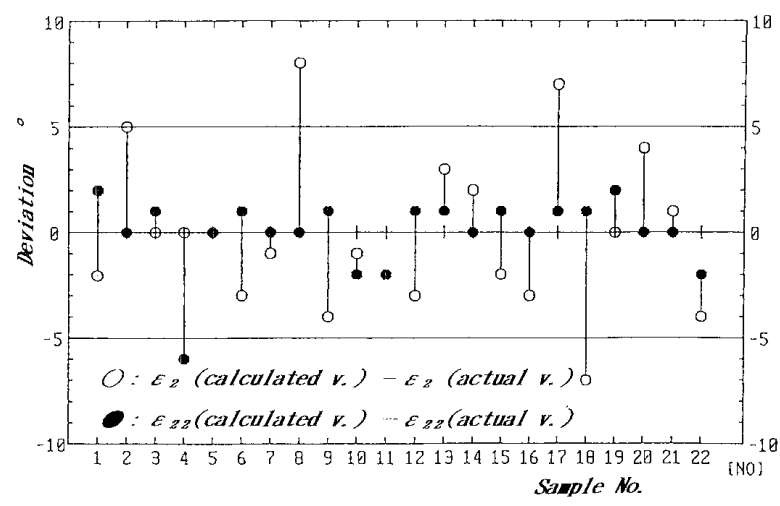

Fig. 9 Comparison of the calculated values with measured values on the back-bending angle in the primary flow of chip

$\begin{array}{lrl}\text { 切りくず内逆折れ層厚さ比: } & \mathrm{t}_{2 \mathrm{~L}} / \mathrm{t}_{2}=0.27 \\ \text { 工具すくい角: } & \gamma_{\mathrm{T}}=11^{\circ} \\ \text { 楔形構成刃先のすくい角: } & \gamma_{\mathrm{B}}=37^{\circ} \\ \text { 第 } 1 \text { せん断角: } & \phi_{1}=22^{\circ} \\ \text { 自由面側第 } 2 \text { せん断角: } & \phi_{2}=66^{\circ} \\ \text { すくい面側 第 } 2 \text { せん断角: } & \phi_{21}=115^{\circ} \\ \text { すくい面側第 } 3 \text { せん断角: } & \phi_{22}=43^{\circ}\end{array}$

と測定できるので，これらから前項の諸式により流れ 角を計算し，実測値と比較すると，

自由面㑬流扎角 $\varepsilon_{2}$ ：計算値 $66.2^{\circ}$ ，夷測值 $64^{\circ}$ すくい面側流れ角 $\varepsilon_{22}$ ：計算值 $79.6^{\circ}$ ，実測值 $82^{\circ}$

となった，同様に，急停止試料の 22 例の写真について 計算值と実測值を比較した。その結果を図 9 に示す。

図 9 は切りくず内の金属組織の流れがすくい面側で 逆折れを起こしている場合に，前項で述べた四つの単 一世ん断面によって生じるとした模型にもとづく計算 值と実測値の比較を示している。すなおち，22例の急 停止写真のそれぞれについて上記の例と同様に前項の 諸式によって自由面側の流㶦 $\varepsilon_{2}$ を計算し, 実測值 の $\varepsilon_{2}$ との差を求め図 9 にととして打点した。同じよ うにすくい面側流れ角 $\varepsilon_{22}$ についても計算値と実测値 との差をのとして, 各切削急停止写真例ごとに示した。

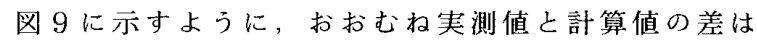
すくい面側で \pm 3 度, 自由面側で \pm 8 度以内であり, 提案した切削機構模型が妥当なものと考える，全体的
にすくい面側の流れ角の実測值と計算值の差 $\varepsilon_{22}$ よ りも自由面側のそれらの差 $\varepsilon_{2} \bigcirc$ ○方が \pm 8 度と大き い.これは図7 (a) の切削機構模型において, せん断 面 C E が状況によっては模型に示した位置ではなく, たとえば，自由面上のC点が少し変動し，その結果第 2 の女ん断角 $\phi_{2}$ が模型の角度で作用していない場合 があることを意味すると考えられる。

以上総合して，切りくず内の金属組織の流れの逆折 れについて，単一せん断面を四つ組合わせた切削機構 模型を提案し, 切削急停止写真からその妥当性を検証 した。

\section{結論}

切りくず内の金属組織の流れがすくい面側で 2 次塑 性流れとは逆の方向に折れ曲がる現象について，四つ の単一世九断面をもつ切削機構模型を提案し，それに もとづいて計算検討した結果つぎのことが分かった。

1 ）切りくず内の金属組織が逆折れを起こすのは, 工 具刃先に小さな楔形の構成刃先が生じ，切りくずが その構成刃先によって生じた後, 工具すくい面に衝 撃的に当たり再度せん断変形を受けるからである。

2 ）提案した模型にもとづいて, 切りくず内の金属組 織の流れ角を自由面側，すくい面側の各々について 計算し，実測值と比較したところほほ合致しこの 切削機構模型が妥当であることがわかった。

$$
\text { 参考 文 献 }
$$

(1) Opitz,H. und Hucks, H., Werkstattstechnick, 43-6 (1953), 253.

（2）奥島·人見，機論，26-163（昭 35），423.

(3) Saffer, B., Trans. ASHE, 77 (1955), 331.

（4）谷口, 精密機械, 29-2 (昭 38), 129.

(5) Pозенбер, A. M. n Epenh, A. H. (長谷川訳), 金属切削 理論, (昭 40), 37. 東京図書.

(6) Hil1, Plasticity, (1950), 206 229, 325 327, 0xford.

(7) Heginbotham, B., Proc. Inst. Mech. Eng., 175-18 (1961).

（8）上神・玉村, 機論, 48-432（昭 57)， 1254.

（9）上神・ほか 2 名, 機論, 40-332（昭 49），1231.

（10）上神・ほか 2 名，精密機械，40-10，（昭 49）858.

（11）上神 · 玉村, 機論， 57-535 (1991-3)， 996.

（12）星，金属切削，（1960），工業調査会.

（13）星・星，金属切削技術，（1969），工業調查会，19. 